\title{
A Method for Determining the Nutritive Value of a Protein by its Effect on Liver Protein
}

\author{
BY KATHLEEN M. HENRY \\ National Institute for Research in Dairying, University of Reading \\ AND \\ H. W. KOSTERLITZ AND M. H. QUENOUILLE \\ Department of Physiology and Department of Statistics, University of Aberdeen
}

(Received 16 fanuary 1952)

Addis, Lee, Lew \& Poo (1940) showed that the liver protein of rats increased with rising casein intake. Yuen, Poo, Lew \& Addis (1940) found that there was considerable variation in the efficacy of different proteins, e.g. yeast protein raised liver protein less than casein. Kosterlitz (1944) confirmed and extended these findings and suggested that it should be possible, using these facts, to evolve a method for the evaluation of the nutritive value of proteins. Several authors followed up this suggestion (Harrison \& Long, 1945; Campbell \& Kosterlitz, 1948; Guggenheim \& Buechler-Czaczkes, I950; Arnrich, Hunt, Axelrod \& Morgan, I95 I), but so far no really workable method has been devised. In some of these studies the conditions of the test were not optimal so that misleading results were obtained and in others the method employed was cumbersome. In the present work, use has been made of the fact that with small protein intakes the increase in total liver nitrogen is sufficiently linear to make protein assay possible.

\section{EXPERIMENTAL AND RESULTS}

\section{Design of assays}

In their attempt to assess the nutritive value of proteins by their effect on liver protein or cytoplasm, Campbell \& Kosterlitz (1948) used adult rats and fed the test proteins in quantities corresponding to $50-800 \mathrm{mg}$ nitrogen/day/roo $\mathrm{g}$ body-weight. It was found that for this range the relationship between $\log \mathrm{N}$ intake and liver protein or cytoplasm was linear. The dose-response relationship is shown in Fig. I. Later it was shown that for small casein- $\mathrm{N}$ intakes, namely $0-190 \mathrm{mg}$ casein- $\mathrm{N} /$ day/100 $\mathrm{g}$ body-weight, the amount of liver protein varied directly with $\mathrm{N}$ intake (Campbell \& Kosterlitz, 1950). This fact is the basis of the design used in the present paper.

Litter-mate rats were distributed in such a way that two rats were fed on diets containing the test proteins in concentrations of $a$ and $2 a$ (see p. 53). Three or four different proteins were examined in any one test. With three proteins, six litters of six rats each were used, and with four proteins, eight litters of eight rats each. In this way, three or four regression lines were obtained which were required to meet at zero protein intake. In some experiments, an additional rat was fed on the protein-free diet in order to obtain a further check on the linearity of the regression lines. In such 
cases where, for example, three proteins were tested, seven litters of seven rats each were used (Fig. 2). Whether additional rats were used or not, litter-mates were

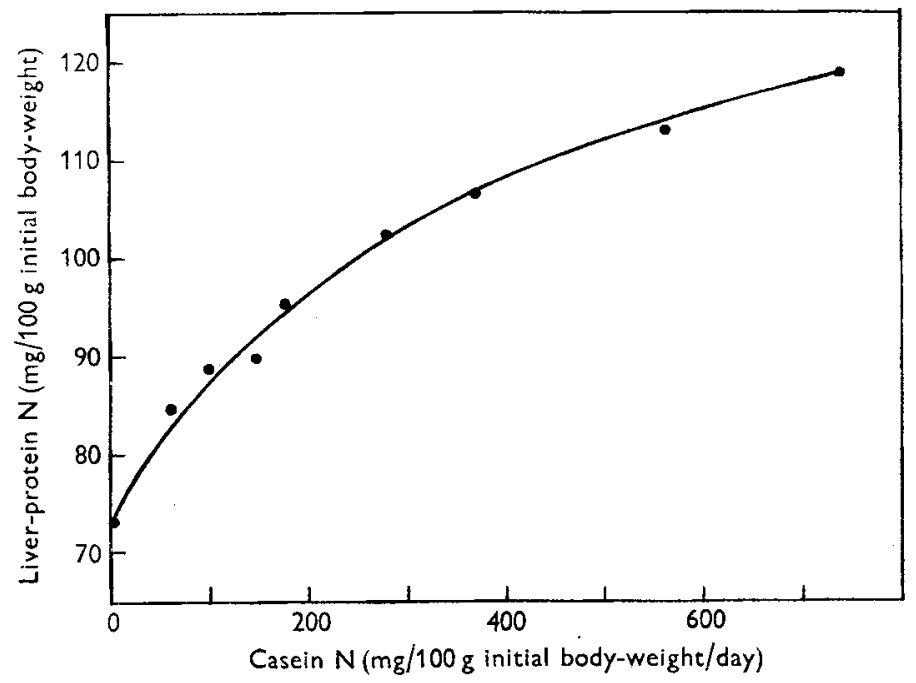

Fig. I. The effect of varying casein intakes on the protein content of the livers of adult rats. Each point represents the mean value obtained with fout to six rats. The line was drawn by eye.

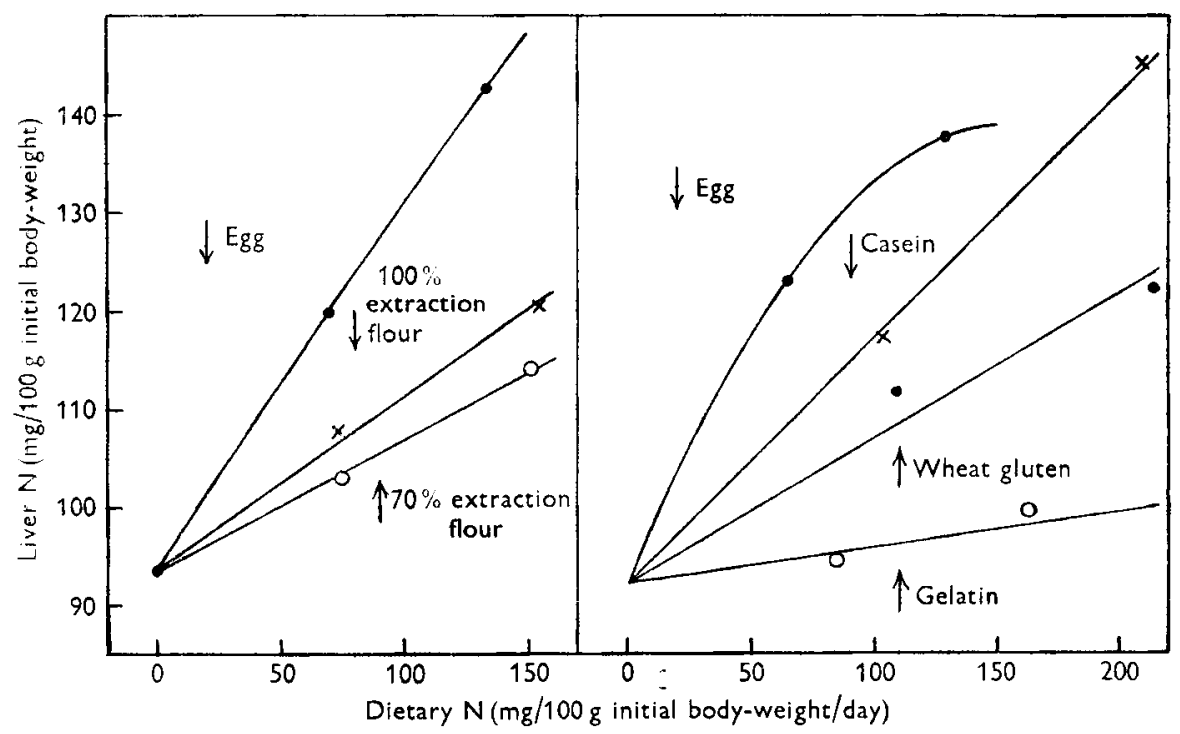

Fig. 2. The effect of various proteins on the total nitrogen contents of livers of young rats. The lines are drawn from the regression equations given in Table 2 . The points represent the non-adjusted means.

assigned to the different diets according to a Latin-square design, with litters as rows and order of body-weights within litters as columns, i.e. the heaviest rats in each litter going into the first column, the next heaviest into the second column and so on. 
The use of this design was not essential, but by its means it was possible to estimate the relative nutritive values of different proteins with a high accuracy. If the littermates and weight ordering had not been employed, the same accuracy could have been attained only by using a much larger number of animals.

The choice of the protein concentration $a$ (p. $5 \mathrm{I}$ ) was determined by the following considerations. If the relationship between liver protein and dietary protein intake is linear, as it seems to be with all proteins but whole-egg protein, the precision with which the slopes of the regression lines can be determined increases with increasing $a$. There is, however, an upper limit: first, the regression eventually becomes significantly non-linear with high protein intakes and, secondly, rats find certain proteins unpalatable in high concentrations. For these reasons the values of $a$ used in the present experiments varied between 5 and $8 \%$. It is not necessary that in any one assay the test proteins should be given at the same levels although this facilitates the statistical evaluation of the results.

\section{General procedure}

Rats. Hooded Norwegian litter-mate male rats bred at Shinfield were used. In the experiments with young rats litter-mates weighed about $100 \mathrm{~g}(80-120 \mathrm{~g})$; in those with adult rats the animals. were 4-6 months old and weighed some $300-45^{\circ} \mathrm{g}$.

Diets. The composition of the basal nitrogen-free diet was sugar I2, potato starch Io, margarine fat Io, salts (de Loureiro, I93I) 4 and rice starch $64 \%$. Table $\mathrm{I}$ lists the protein sources tested and gives the percentage of $\mathrm{N}$ in the experimental diets; the appropriate amount of the protein to be tested was substituted for an equal weight of the rice starch (rice starch and sugar in Exps. 4 and 9). In the experiments with flours (Exps. 4 and 9) the percentage of both margarine fat and potato starch in the basal diet was reduced to 7 and that of rice starch increased to 70 . The manufacture and storage conditions of the dried skim-milk samples have been described by Henry, Kon, Lea \& White (1948); the samples used were their high-moisture milk powders (stored in air or $\mathrm{N}_{2}$ for 60 days at $37^{\circ}$ ) and their control milk powder. Vitamin-free casein (Glaxo Laboratories Ltd.) was used in Exps. 5, 6 and 7. Each rat was given daily, on a separate dish, $0.5 \mathrm{ml}$. of the mixture of water-soluble vitamins described by Campbell \& Kosterlitz (1948). Vitamins A and D were supplied as cod-liver oil.

The amount of food eaten is of some importance since it has been shown that a reduction in calorie intake reduces the sensitivity of the method (Campbell \& Kosterlitz, 1948). Except in Exp. I, young rats were offered 9 and adult rats $6 \mathrm{~g} / \mathrm{100} \mathrm{g}$ initial body-weight each day. The experimental-feeding period with the protein-free diet was 5 days and with the diets containing test proteins 7 days in Exps. I, 8 and 9. In all other experiments with young rats the feeding period was extended to Io days, a modification that was found to produce more uniform results than the 7-day period. The food intakes over the whole period were recorded for each rat and in Exps. 3-7 and 9 the daily intake was measured on each of the last 4 days of the feeding period. Since with some of the less palatable proteins the food intake might vary, it was necessary to test the possible effect of such variations by analysis of covariance and make the appropriate adjustments (see statistical appendix). 
Table I. Litters used; description of proteins tested; percentage of nitrogen in the experimental diets; food and nitrogen intakes; weight change of rats during to days

No. of

Exp. litters

no. used*

I† 7 (7) Control dried skim milk (fed ad lib.)

Control dried skim milk (equalized intake) $\ddagger$

High-moisture dried skim milk; stored for 60 days at $37^{\circ}$ in air-pack

$2 \quad 8$ (8) Ether-extracted whole dried egg

Control dried skim milk

High-moisture dried skim milk; stored for

60 days at $37^{\circ}$ in gas-pack

High-moisture dried skim milk; stored for 60 days at $37^{\circ}$ in air-pack

$3 \quad 8(8) \quad$ Ether-extracted whole dried egg

Control dried skim milk

High-moisture dried skim milk; stored for 60 days at $37^{\circ}$ in air-pack

High-moisture dried skim milk; stored for 60 days at $37^{\circ}$ in air-pack, supplemented with $\mathrm{I} \cdot 25 \%$ L-lysine

$4 \quad 7(7) \quad$ Ether-extracted whole dried egg

Flour: $70 \%$ extraction

$$
\text { I00\% extraction }
$$

$5 \quad 7(7) \quad$ Ether-extracted whole dried egg

Vitamin-free casein

Soya-bean meal

$6 \quad 8$ (8) Ether-extracted whole dried egg

Vitamin-free casein

Gelatin

Wheat gluten

76 (6) Ether-extracted whole dried egg

Control dried skim milk

Vitamin-free casein

$8 \dagger$ 10 (7) Control dried skim milk

High-moisture dried skim milk; stored for 60 days at $37^{\circ}$ in air-pack

of 7 (7) Ether-extracted whole dried egg

Flour: $70 \%$ extraction

$$
100 \% \text { extraction }
$$

Mean daily $\quad$ Mean daily
food intake $\quad \mathrm{N}$ intake

(g/100 g

$\mathbf{N}$ in diet initial body-

$$
\text { (mg/roo g }
$$

\begin{tabular}{|c|c|c|c|c|}
\hline$(\%)$ & weight) & weight) & Initial & Final \\
\hline $1 \cdot 27$ & $8 \cdot 6$ & $109 \cdot 2$ & 107 & 105 \\
\hline 2.53 & $7 \cdot 5$ & $189 \cdot 8$ & 107 & 109 \\
\hline $1 \cdot 27$ & $7 \cdot 6$ & $96 \cdot 5$ & 105 & 99 \\
\hline $2 \cdot 53$ & $7 \cdot 2$ & $18 z \cdot 2$ & 107 & 105 \\
\hline $1 \cdot 27$ & 8.0 & $101 \cdot 6$ & 107 & 99 \\
\hline $2 \cdot 49$ & $7 \cdot 5$ & $186 \cdot 7$ & 106 & 102 \\
\hline $1 \cdot 27$ & $7 \cdot 1$ & $90 \cdot 2$ & 117 & 117 \\
\hline $2 \cdot 48$ & $7 \cdot 7$ & 191.0 & 117 & 128 \\
\hline $1 \cdot 28$ & $8 \cdot 0$ & IO2.4 & 118 & I 19 \\
\hline 2.52 & $7 \cdot 9$ & $I 99^{\circ} \mathrm{I}$ & 118 & 128 \\
\hline $1 \cdot 25$ & $7 \cdot 8$ & $97 \cdot 5$ & 118 & I I I \\
\hline 2.43 & $7 \cdot 8$ & 189.5 & 117 & I I 8 \\
\hline $1 \cdot 24$ & $8 \cdot I$ & 100.4 & 117 & II3 \\
\hline $2 \cdot 43$ & $8 \cdot 1$ & $196 \cdot 8$ & (18 & 123 \\
\hline 0.92 & $8 \cdot 6$ & $79^{\prime} I$ & 107 & 105 \\
\hline $\mathrm{I} \cdot 78$ & $8 \cdot 4$ & 149.5 & 106 & 109 \\
\hline 0.95 & $8 \cdot 5$ & $80 \cdot 7$ & I06 & IOI \\
\hline I. 88 & $8 \cdot 4$ & I 58.0 & 106 & 104 \\
\hline 0.93 & $8 \cdot 2$ & $76 \cdot 3$ & 105 & 95 \\
\hline$I \cdot 81$ & $8 \cdot 3$ & 150.3 & 106 & 103 \\
\hline 0.97 & $8 \cdot 5$ & $8 z \cdot 5$ & 108 & 98 \\
\hline 1.90 & 8.6 & $163 \cdot 4$ & 106 & 103 \\
\hline
\end{tabular}

initial body-

0.78

$\mathrm{r} \cdot 58$

0.89

$1 \cdot 78$

0.86

$1 \cdot 74$

0.90

r'79

0.94

$\mathrm{I} \cdot 86$

I. 00

I.96

0.83

$1 \cdot 53$

$1 \cdot 29$

$2 \cdot 45$

I. 29

$2 \cdot 63$

$\mathrm{I} \cdot 28$

$2 \cdot 57$

0.77

$\mathrm{I} \cdot 57$

$\mathrm{I} \cdot 28$

2.43

I. 27

2. 52

I. 30

2.55

I. 27

2.45

0.72

I. 54

0.89

I. 63

0.84

$\mathrm{I} \cdot 72$

\section{$8 \cdot 7$}

8. 5

$8 \cdot 7$

8.5

8.7

$8 \cdot 9$

8.8

$8 \cdot 1$

$8 \cdot 4$

7.8

$7 \cdot 9$

$8 \cdot 2$

$7 \cdot 7$

$8 \cdot 4$

$8 \cdot 0$

$8 \cdot 6$

$6 \cdot 6$

$6 \cdot 2$

$8 \cdot 5$

$8 \cdot 3$

$8 \cdot 3$

8.6

$8 \cdot 5$

$8 \cdot 3$

$8 \cdot 4$

$7 \cdot 5$

$5 \cdot 5$

$5 \cdot 2$

$5 \cdot 7$

5.0

4.6

4.8

$4 \cdot 5$

5.4

$4 \cdot 7$

5.0

$67 \cdot 8$

$\times 34.3$

$77 \cdot 5$

$15 \mathrm{I} \cdot 3$

74.8

154.8

$79^{\circ} 2$

$145^{\circ} \circ$

$79^{\circ} 0$

I $45^{\circ} \mathrm{I}$

$79^{\circ} 0$

160.7

64.2

$128 \cdot 6$

103.4

$209^{\circ} 4$

$84 \cdot 8$

I63. I

IO9. 4

213.9

$64 \cdot 1$

I 34.7

108.5

$201 \cdot 7$

106.9

190.0

71.5

132.0

$72 \cdot 3$

122.7

$32 \cdot 4$

$73 \cdot 4$

$39 \cdot 6$

$87 \cdot 9$

39.5

86.7

$100 \quad 95$

$100 \quad 103$

IOI 90

99

100

99

I 4

II 4

II 4

II 4

II 4

I 13

94

97

94

96

93

95

95

95

96

96

97

96

96

96

382

380

391

394

393

401

395

395

399

$394 \quad 404$

* Figure in parentheses is the number of rats in each litter.

† Experimental period lasted for 7 days.

$\ddagger$ Diet equalized with that of animals given the stored-milk diets. 
Analysis of livers. At the end of the feeding period the rats were anaesthetized with a mixture of alcohol-ether-chloroform ( $1: 2: 3)$, the abdominal and thoracic cavities were opened rapidly, and the body drained of blood after heart-puncture. The liver was then quickly removed, washed under running water, dried in filterpaper, weighed, minced with scissors and two $\mathrm{I} g$ samples were taken for nitrogen determination by the macro-Kjeldahl method as a measure of liver protein.

Calculation of results. It has been shown (Kosterlitz, 1947; Mandel, Jacob \& Mandel, 1950) that although in adult rats fed on protein-deficient diets there are losses in body and liver weights, there is no decrease in the number of liver nuclei. For this reason, the correct procedure appeared to be to relate the results of liver analyses to the initial, and not to the final, body-weights, although this may exaggerate the results obtained with high-grade proteins in young rats, which continue to grow during the experimental period when fed on such proteins. Thus, the analytical results were expressed as $\mathrm{mg}$ total liver $\mathrm{N} / \mathrm{IoO} \mathrm{g}$ initial body-weight. The regressions of these values on the mean dietary $\mathrm{N}$ intake ( $\mathrm{mg} / \mathrm{ro0} \mathrm{g}$ initial body-weight/day) were calculated after elimination of the effects caused by differences between litters, and of variations in body-weight and food intake. If the regressions were linear, the ratio of the slopes of the lines obtained for two proteins was taken to be the ratio of their nutritive values. When egg protein was used as the reference protein, a different procedure had to be adopted since the regression was usually significantly non-linear. In this instance, the liver $\mathrm{N}$ was calculated for the mean protein intake and the ratio of the liver- $\mathrm{N}$ contents at this level of intake was considered to give the ratio of the nutritive values of the proteins. A detailed discussion of the statistical procedure will be found in the appendix.

\section{Experiments with young rats}

Exp. I. Seven litters of seven rats were used. Litter-mates were given, unrestricted, the 'nitrogen-free' diet (p. 53), or diets containing 8 or $16 \%$ protein supplied by the control milk or the high-moisture air-packed milk stored for 6 months at $37^{\circ}$. The remaining two rats in each litter were given the control milk diets, and their food intake was equalized with that of the animals given the corresponding stored-milk diets. This was done to test if restriction of food intake influenced the results, since preliminary experiments had suggested that the stored-milk diets were less readily eaten by rats than the control-milk diets.

The results (Tables I and 2) show that storage significantly lowered the nutritive value of the proteins of milk with a high moisture content $(P<0.01)$. This is in agreement with the findings of Henry et al. (I948) who used the balance-sheet method (Mitchell, 1923-4; Mitchell \& Carman, 1926). The results also show that similar values were obtained whether the diets were given unrestricted or whether the intake was equalized between litter-mates.

Exps. 2 and 3. In both experiments eight litters of eight rats were used. In Exp. 2 ether-extracted whole dried egg, control and stored air- and gas-packed samples of milk (cf. Henry et al. 1948; Henry \& Kon, I952a) were tested at the 8 and $16 \%$ levels of protein intake. The egg was included as a standard source of protein, usually 
assumed to be completely utilized, so that results obtained by this method could be compared with those obtained for the same milk samples by the balance-sheet method (Henry \& Kon, 1952a). In Exp. 3 the following foods were tested at 6 and $12 \%$ levels of protein intake: whole egg, control milk and stored gas-pack milk alone or supplemented with $\mathrm{I} \cdot \mathbf{2 5} \% \mathrm{~L}$-lysine.

Table 2. Nutritive values of proteins determined on young rats (Exps. I-7) and on adult rats (Exps. 8 and 9)

Exp.

\begin{tabular}{|c|c|}
\hline no. & Protein tested \\
\hline I & $\begin{array}{l}\text { Control milk } \\
\text { Air-packed milk } \\
\text { Control milk, pair-fed }\end{array}$ \\
\hline 2 & $\begin{array}{l}\text { Egg } \\
\text { Control milk } \\
\text { Gas-packed milk } \\
\text { Air-packed milk }\end{array}$ \\
\hline 3 & $\begin{array}{l}\text { Egg } \\
\text { Control milk } \\
\text { Gas-packed milk } \\
\text { Gas-packed milk with I·25\% L- } \\
\text { lysine }\end{array}$ \\
\hline 4 & $\begin{array}{l}\text { Egg } \\
\text { Flour: } 70 \% \text { extraction } \\
\\
100 \% \text { extraction }\end{array}$ \\
\hline 5 & $\begin{array}{l}\text { Egg } \\
\text { Casein } \\
\text { Soya }\end{array}$ \\
\hline 6 & $\begin{array}{l}\text { Egg } \\
\text { Casein } \\
\text { Wheat gluten } \\
\text { Gelatin }\end{array}$ \\
\hline 7 & $\begin{array}{l}\text { Egg } \\
\text { Control milk } \\
\text { Casein }\end{array}$ \\
\hline 8 & $\begin{array}{l}\text { Control milk } \\
\text { Air-packed milk }\end{array}$ \\
\hline 9 & $\begin{array}{l}\text { Egg } \\
\text { Flour: } 70 \% \text { extraction } \\
\\
\text { I00\% extraction }\end{array}$ \\
\hline
\end{tabular}

\begin{tabular}{|c|}
\hline $\begin{array}{c}\text { Regression equation } \\
(y=\text { liver } N \text { in mg/roo } \mathrm{g} \\
\text { initial body-weight } \\
x=\text { dietary } N \text { in } \mathrm{mg} / \mathrm{roo} \mathrm{g} \\
\text { initial body-weight } / \text { day })\end{array}$ \\
\hline $\begin{array}{l}y=90 \cdot 4+0.212 x \\
y=90.4+0.162 x \\
y=90.4+0.200 x\end{array}$ \\
\hline $\begin{array}{l}y=87.3+0.553 x-0.00105 x^{2}+ \\
y=87.3+0.344 x \\
y=87.3+0.267 x \\
y=87.3+0.279 x\end{array}$ \\
\hline $\begin{array}{l}y=90.8+0.704 x-0.00191 x^{2} \dagger \\
y=90.8+0.285 x \\
y=90.8+0.203 x \\
y=90.8+0.260 x\end{array}$ \\
\hline $\begin{array}{l}y=93 \cdot 4+0.414 x-0.00035 x^{2} \\
y=93 \cdot 4+0.135 x \\
y=93^{\cdot} 4+0.178 x\end{array}$ \\
\hline $\begin{array}{l}y=87.6+0.730 x-0.00207 x^{2} \dagger \\
y=87.6+0.284 x \\
y=87.6+0.17 \mathbf{I} x\end{array}$ \\
\hline $\begin{array}{l}y=92.3+0.615 x-0.00203 x^{2} \uparrow \\
y=92 \cdot 3+0.250 x \\
y=92 \cdot 3+0.147 x \\
y=92.3+0.037 x\end{array}$ \\
\hline $\begin{array}{l}y=9 \mathrm{r} \cdot 2+0 \cdot 680 x-0.00194 x^{2} \dagger \\
y=9 \mathrm{r} \cdot 2+0 \cdot 295 x \\
y=9 \mathrm{r} \cdot 2+0 \cdot 28 \mathrm{I} x\end{array}$ \\
\hline $\begin{array}{l}y=75.9+0.254 x \\
y=75.9+0.244 x\end{array}$ \\
\hline $\begin{array}{l}y=70.0+0.685 x-0.00320 x^{2}+ \\
y=70.0+0.220 x \\
y=70.0+0.225 x\end{array}$ \\
\hline
\end{tabular}

\begin{tabular}{|c|c|c|}
\hline $\begin{array}{l}\text { Increase in } \\
\text { liver } N \text { for } \\
\text { intake of } \\
\text { roo mg N/roo } \mathrm{g} \\
\text { initial body- }\end{array}$ & $\begin{array}{r}\text { Nutritiv } \\
\text { protein } \\
\text { standa } \\
\text { calcul }\end{array}$ & $\begin{array}{l}\text { ve value of } \\
n \text { with its } \\
\text { ard error } \\
\text { lated for }\end{array}$ \\
\hline (mg) & $\mathrm{Egg}=100$ & Casein $=100$ \\
\hline $\begin{array}{l}21 \cdot 2 \\
16 \cdot 2\end{array}$ & - & - \\
\hline $20 \cdot 0$ & - & - \\
\hline $\begin{array}{l}44.8 \\
34 \cdot 4\end{array}$ & $\overline{77 \pm 4 \cdot 0}$ & - \\
\hline $\begin{array}{l}34+ \\
26 \cdot 7 \\
27 \cdot 9\end{array}$ & $\begin{array}{l}60 \pm 3.6 \\
62 \pm 3.7\end{array}$ & - \\
\hline $\begin{array}{l}5 x \cdot 3 \\
28 \cdot 5\end{array}$ & $\overline{5^{6} \pm 5 \cdot 0}$ & - \\
\hline $20 \cdot 3$ & $40 \pm 5 \cdot 1$ & - \\
\hline $26 \cdot 0$ & $5 \div \pm 4.9$ & - \\
\hline $37 \cdot 9$ & - & - \\
\hline I 3.5 & $3^{6} \pm 4^{\cdot} \cdot 6$ & - \\
\hline 17.8 & $47 \pm 4.7$ & - \\
\hline $52 \cdot 3$ & - & - \\
\hline $28 \cdot 4$ & $54 \pm 5.5$ & - \\
\hline $17 \cdot 1$ & $33 \pm 5 \cdot 3$ & $60 \pm 9 \cdot 5$ \\
\hline $4 I \cdot 2$ & - & - \\
\hline $25^{\circ} \mathrm{O}$ & $6 x \pm 3.5$ & - \\
\hline $14 \cdot 7$ & $36 \pm 3 \cdot 5$ & $59 \pm 5^{\circ} 0$ \\
\hline 37 & $9 \pm 5 \cdot 4$ & $15 \pm 9.4$ \\
\hline $49^{\circ} 6$ & - & - \\
\hline $\begin{array}{l}29 \cdot 5 \\
28 \cdot I\end{array}$ & $\begin{array}{l}59 \pm 5 \cdot 3 \\
57 \pm 5 \cdot 3\end{array}$ & $\begin{array}{c}105 \pm 8 \cdot 9 \\
-\end{array}$ \\
\hline I5.3 & - & - \\
\hline $14 \cdot 6$ & - & - \\
\hline $29 \cdot 6$ & 一 & - \\
\hline $13 \cdot 2$ & $45 \pm 7 \cdot 0$ & - \\
\hline I3.5 & $46 \pm 7 \cdot 0$ & - \\
\hline
\end{tabular}

* In Exps. 8 and 9 the values in this column were increases in liver $\mathrm{N}$ for intake of $60 \mathrm{mg} \mathrm{N} / 100 \mathrm{~g}$ initial body-weight/day.

$\dagger$ Quadratic term significantly different from zero.

The results of Exps. 2 and 3 are given in Tables I and 2; they demonstrate that the loss of nutritive value $(P<0.001$ and $P<0.01)$ of the proteins of stored milk with a high moisture content can be restored by the addition of lysine. These results confirm those obtained by Henry et al. (I948) for similar samples of milk by the balance-sheet method.

Exp. 4. Seven litters of seven rats were used. Whole egg and flours of 70 and $100 \%$ 
extraction prepared from one grist (60\% Manitoba and $40 \%$ English wheat) were tested at the 5 and 10\% levels of protein intake. These were the highest protein levels possible on account of the low protein content of the flours.

It was found (Tables $I$ and 2) that for young growing rats the proteins of $100 \%$ extraction flour were superior in nutritive value to those of $70 \%$ extraction flour $(P<0.05)$.

Exp. 5. Seven litters of seven rats were used. The animals were given the proteinfree diet or diets containing 6 or $12 \%$ protein derived from whole egg, casein or defatted soya-meal (heat-treated). The value obtained for soya-meal was surprisingly low, amounting to only $60 \%$ of the value for casein (Tables $I$ and 2).

Exp. 6. Eight litters of eight rats were used. Whole egg was tested at 5 and $10 \%$ levels of protein intake; casein, gelatin and wheat gluten were tested at 8 and $16 \%$ levels of protein intake (Tables $I$ and 2 ). General agreement was found with values obtained by the balance-sheet method when casein was used as reference (Table 6).

Exp. 7. In this experiment a direct comparison was made between dried skim milk and casein. Six litters of six rats were used. Whole egg was tested at 5 and $10 \%$ protein levels; control milk (Henry \& Kon, r952a) and casein were tested at 8 and $16 \%$ levels of protein intake.

There was no significant difference between the nutritive values of casein and milk proteins (Tables $I$ and 2). This agrees with results obtained by the balance-sheet method for the biological value of the same samples of milk (Henry \& Kon, 1952a) and of casein (Henry \& Kon, I952b).

\section{Experiments with adult rats}

Exp. 8. In this experiment, which was the first of the series presented in this paper, the design differed somewhat from that used in the other experiments. The control and air-pack stored milks (Henry \& Kon, 1952, a) were given at the 8 and $16 \%$ protein levels. In each of ten litters of seven rats, one rat was given the protein-free diet, one the $8 \%$ control-milk diet, one the $8 \%$ stored-milk diet, and two rats each of the $16 \%$ protein diets. This was done because of the marked tendency of adult rats, observed in preliminary tests, to eat inadequate amounts of high-protein diets; of the pairs of rats fed on the $16 \%$ protein diet, the results of those with the lower food intakes were discarded. Thus ten litters of five rats were used for the calculation of the results (Tables I and 2). With adult rats no difference was detected between the control and stored samples of milk. This is in agreement with results obtained by Henry \& Kon (1952a) for the same milk samples by the balance-sheet method.

Exp. 9. In this repetition of Exp. 4 seven litters of seven 4 -month-old rats were used. In contrast to the findings with young rats, no differences were detected in the nutritive values of the proteins of flours of 70 and $100 \%$ extraction (Tables $I$ and 2 ).

\section{DISCUSSION}

The finding (Campbell \& Kosterlitz, r950) that for relatively small $\mathrm{N}$ intakes the value of liver protein/100 $\mathrm{g}$ initial body-weight varies directly with the amount of casein eaten (protein $\mathrm{N} / 100 \mathrm{~g}$ body-weight/day) has now been extended to a number 
of other proteins, namely, those of milk, flour and soya-bean, and gelatin. The only exception found so far is whole-egg protein. Since the rate of increase in liver protein is small with proteins of low nutritive value and large with those of high nutritive value, deviations from linearity of the early part of the dose-response curve (Fig. I) are most likely to occur with high-grade proteins. For egg protein, the increase in liver protein was in most tests significantly non-linear whereas for the next best proteins, milk proteins and casein, a significant deviation was not found.

Table 3. Comparison of nutritive values for young rats of the proteins of the same milk powders, obtained with the liver-protein, balance-sheet and growth methods (control milk taken as $\mathrm{100})$

\begin{tabular}{|c|c|c|c|c|c|c|c|}
\hline \multirow[b]{2}{*}{ Protein tested } & \multicolumn{3}{|c|}{$\begin{array}{l}\text { Liver method } \\
\text { Exp. no.* }\end{array}$} & \multicolumn{3}{|c|}{$\begin{array}{l}\text { Balance-sheet method } \\
\text { Exp. no. } \dagger\end{array}$} & \multirow{2}{*}{$\begin{array}{c}\text { Growth } \\
\text { method } \\
\text { Exp. no. } \dagger \\
2\end{array}$} \\
\hline & I & 2 & 3 & 2 & 3 & 4 & \\
\hline Control milk & 100 & 100 & 100 & I00 & 100 & 100 & 100 \\
\hline Stored gas-pack milk $\ddagger$ & - & 78 & 71 & 69 & - & $\ldots$ & 64 \\
\hline Stored air-pack milk $\ddagger$ & 76 & $8 I$ & $\div$ & 65 & - & 64 & 56 \\
\hline $\begin{array}{l}\text { Stored gas-pack milk } \downarrow \text { with } 1 \cdot 25 \% \\
\text { L-lysine }\end{array}$ & - & - & $9 I$ & - & 92 & - & - \\
\hline
\end{tabular}

The determination of the nutritive value of a protein by means of its effect on liver protein does not yield absolute values as does the balance-sheet method. In order to compare the nutritive values of two proteins, the slopes of the regression lines of liver $\mathrm{N} / \mathrm{ro0} \mathrm{g}$ initial body-weight on dietary $\mathrm{N}$ intake/roo g initial body-weight/day are estimated statistically. The ratio of the slopes then estimates the ratio of the nutritive values, and if the slopes are significantly different, the nutritive values may be taken to be different. Often no further information is required, as for instance in a comparison of the proteins of 70 and $100 \%$ extraction flours or in an investigation of the effects of storage on high-moisture skim-milk powder. It is then sufficient to assign a value of 100 to the best protein and express the others as a percentage of it. This has been done, e.g. for the stored milk powders (Table 3 ).

The choice of a general reference protein has been found somewhat difficult. Ether-extracted egg protein is generally assumed to be completely utilized, and its biological value as estimated by the balance-sheet method is usually close to roo. Unfortunately, the response of liver protein to different intakes of egg protein is not linear; this means that, when referred to whole-egg protein, the nutritive value of a protein, as estimated by the liver method, is not independent of the level of protein intake. This is a very serious disadvantage which, however, is also encountered with the balance-sheet method. Since with casein the dose-response curve is linear for intakes of approximately $200 \mathrm{mgN} / \mathrm{ro0} \mathrm{g}$ body-weight/day, the nutritive value of any other protein with a linear dose-response curve is independent of the $\mathrm{N}$ intake within the limits stated, if referred to casein (Fig. 2). For this reason we consider 
casein, which can be readily obtained in sufficiently pure condition, a more suitable reference standard than egg protein. The nutritive values of a number of proteins, referred to either egg protein or casein taken as 100, are given in Table 4 .

Table 4. Comparison of nutritive values for young rats of proteins tested by the liver-protein method with values reported in the literature for the balance-sheet and growth methods

Liver-protein method

Egg = roo

(Protein-N

intake $=$

Protein

Dried skim milk $\uparrow$

Casein $†$

Flour: $70 \%$ extraction $100 \%$ extraction

Wheat gluten $\dagger$

Soya-bean meal (heated)

Gelatin
$100 \mathrm{mg} / 100 \mathrm{~g}$

body-weight) Casein $=100$

$54,61,57$

36

47

36

33

9

105
100
$63 \S$
$83 \S$
59
60
15

$77,56,59$

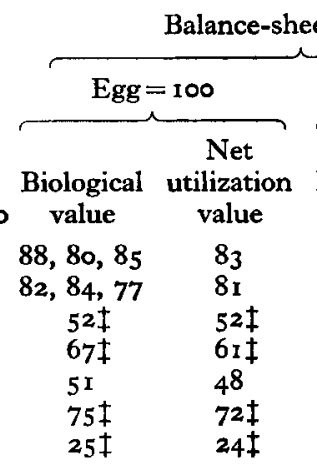

Balance-sheet method

* The biological values referred to casein $=100$ were obtained by dividing the biological values (referred to egg $=100$ ) by $0.8 \mathrm{r}$, i.e. the mean biological value of casein divided by 100 .

+ The same samples of milk, casein and wheat gluten were used for the determination of the nutritive or biological values by the liver-protein and balance-sheet methods. The individual values quoted for dried skim milk and casein in columns 2 and 4 were obtained in separate experiments (cf. Table 2 of the present paper; Henry \& Kon, I952a, b).

† Block \& Mitchell (1946-7).

$\S$ Since no direct comparisons were made between the proteins of the flours and casein, these values were obtained by dividing the values calculated for $\mathrm{egg}=100$ by 0.57 .

If Chick (1942).

The nutritive values obtained by the present method cannot be properly compared with the biological values of the balance-sheet method; in the former the values of liver $\mathrm{N}$ are related to the amount of $\mathrm{N}$ eaten and in the latter the amount of $\mathrm{N}$ retained is related to that of $\mathrm{N}$ absorbed. However, it is permissible to compare the nutritive value obtained with the liver method with the net utilization value of the balance-sheet method, namely, the biological value multiplied by the coefficient of true digestibility and divided by roo. Such a comparison shows that with the exception of soya-bean protein there is fair agreement for the proteins tested (Tables 3 and 4). When egg protein is used as a reference, the values obtained by the liver-protein method are lower than those obtained by the balance-sheet method, although they fall into the same order. The discrepancy is not unexpected in view of the fact that with egg protein as reference, the nutritive values vary with varying protein intake and the protein intake chosen for calculation is quite arbitrary. On the other hand, when casein is used as a reference in both methods the agreement is good.

It is of particular interest to note that in young rats both the liver-protein method and the balance-sheet method demonstrate a loss of nutritive value of milk proteins on storage of powders with a high moisture content (Table 3 ). This deterioration has been shown to be due to interaction between lysine and lactose which renders the lysine unavailable (Henry et al. 1948). Supplementation with I $25 \%$ L-lysine restored 
the nutritive value as measured by both methods. In adult rats, on the other hand, no loss of nutritive value could be detected by either of the two methods (Table 2; Henry \& Kon, $1952 a$ ). These findings agree with the well-known fact that growing rats are much more sensitive to lysine deficiency than adult animals (Neuberger \& Webster, 1945; Mitchell, 1947).

Similarly, no difference was found for 70 and $100 \%$ extraction flours when adult rats were used, a finding which agrees with the results of Campbell \& Kosterlitz (1948). In young rats, however, the $100 \%$ extraction flour was significantly superior to the $70 \%$ extraction flour. This confirms the findings of Chick, Copping \& Slack (1946) with the growth method. Using breads made from flours of different extraction rates, Henry \& Kon (1945) found higher biological values for bread made from $100 \%$ extraction flour than for that made from $70 \%$ extraction flour. On the other hand, the net utilization values, which take into account the relatively poor digestibility of bread made from $100 \%$ extraction flour, did not show any significant differences between the various breads. The discrepancy between the present findings and those of Chick et al. (1946) on the one hand and of Henry \& Kon (1945) on the other, may possibly be explained by the presence of yeast proteins in bread and by the heating of proteins during baking.

Although a quantitative comparison of the liver-protein method and the growth method is not possible, it would appear that there is no serious discrepancy, again with the exception of the soya-bean meal (Tables 3 and 4 ).

The precision of the liver method is not as good as that of the balance-sheet method used with a suitable design (e.g. Henry \& Kon, 1945). The advantage of the latter is, however, at least partly counterbalanced by the fact that the liver method requires very much less time than the balance-sheet method and is technically very simple.

It is of considerable physiological interest that the amount of protein in the liver gives such a good indication of the nutritive value of a protein. The liver appears to integrate very efficiently the effects of the anabolic and katabolic processes of protein metabolism at any given time. Thus, the amount of protein present in the liver yields information that otherwise can only be obtained by determining the balance between $\mathrm{N}$ intake and output. In view of this fact, the discrepancy found between the liver and the balance-sheet methods with soya-bean protein may become important.

Several attempts have been made previously to assay the nutritive value of a protein by its effect on liver protein, mostly with disappointing results caused by unsuitable experimental design. Thus Guggenheim \& Buechler-Czaczkes (1950) found poor agreement between their liver-protein method and the classical balance-sheet and growth methods. These authors used as a criterion for the nutritive value of the test protein the increase in the concentration of protein in the liver (mg liver $\mathrm{N} / \mathrm{g}$ liver), a procedure of little or no use as it gives no information whatever as to the total amount of protein in the liver. The concentration of liver protein varies readily with changes in the water, glycogen and fat contents of the liver. For this reason, very high concentrations of liver protein are found in fasted animals. It has been shown that these effects of varying glycogen, water and fat contents can only be eliminated 
by relating liver protein either to the body-weight or to the deoxyribonucleic-acid content of the liver (Kosterlitz, 1947; Campbell \& Kosterlitz, 1950, 1952).

Arnrich et al. (195I) used the method of Harrison \& Long (1945) to study the effects of various proteins on liver protein. They found very little difference between the efficacy of casein, gluten and dried defatted whole egg in raising the liver protein of rats which had been fasted. It has been pointed out previously (Campbell \& Kosterlitz, 1948) that in the procedure of Harrison \& Long (1945) the calorie intake is suboptimal, which considerably reduces the sensitivity of the method.

\section{SUMMARY}

I. A new method has been developed for the assay of the nutritive value of proteins. It is based on the following facts. (a) For relatively small protein intakes, the values of $\mathrm{mg}$ liver nitrogen/100 $\mathrm{g}$ initial body-weight varied linearly with the amount of protein eaten. The only exception was whole-egg protein. (b) The slopes of the regression lines obtained by plotting $\mathrm{mg}$ liver $\mathrm{N} / \mathrm{r} 00 \mathrm{~g}$ body-weight against $\mathrm{mg}$ daily $\mathrm{N}$ intake/100 $\mathrm{g}$ body-weight were greater for high-grade than for low-grade proteins.

2. In view of the non-linearity of the response of the liver to egg protein, casein is considered to be the most suitable reference protein. The ratios of the slopes of the regression lines of two or more proteins are taken to be the ratios of their nutritive values.

3. The relative values obtained with the new method for casein, fresh or deteriorated milk powders, flours of different extraction rates, wheat gluten and gelatin agreed well with the values found with the balance-sheet and growth methods. The only exception so far observed was soya-bean protein, for which a lower value was obtained with the new method.

4. The new method is not as time-consuming as the balance-sheet method which, on the other hand, is more sensitive to small differences in nutritive values.

We wish to thank Dr T. Moran and Dr C. R. Jones of the Cereals Research Station, St Albans, for the preparation of the flours and Dr F. H. C. Marriott and Miss M. A. Creasy for help with the statistical analyses. We are indebted to Miss M. V. Chapman for help with feeding of the rats and to Miss V. Glover and Miss M. R. Cooling for help with nitrogen analyses.

\section{A. Estimation of nutritive values}

APPENDIX

To demonstrate the statistical analysis of these experiments the results of Exp. I may be considered. The mean daily nitrogen intake and liver $\mathrm{N}$, both expressed as $\mathrm{mg} / \mathrm{roo} \mathrm{g}$ initial body-weight, for the groups of seven animals were as follows:

\begin{tabular}{|c|c|c|c|}
\hline $\begin{array}{c}\text { Mean N } \\
\text { intake }\end{array}$ & Control milk & $\begin{array}{l}\text { Air-packed } \\
\text { milk }\end{array}$ & $\begin{array}{l}\text { Control milk } \\
\text { pair-fed }\end{array}$ \\
\hline o & $90 \cdot 7$ & $90 \cdot 7$ & $90 \cdot 7$ \\
\hline 95 & III'9 & $104 \cdot 4$ & $108 \cdot 9$ \\
\hline 190 & $131 \cdot 5$ & $121 \cdot 8$ & $127^{\circ} 0$ \\
\hline
\end{tabular}


The regression coefficients may be estimated using the observations on each diet by taking three times the zero level from the sum of the first level and twice the second level. Here this gives:

$$
\begin{aligned}
2 \times 190+95 \cdot 0-3 \times 0 & =475^{\circ} 0 \\
2 \times 131 \cdot 5+111 \cdot 9-3 \times 90 \cdot 7 & =102 \cdot 8, \\
2 \times 121 \cdot 8+104 \cdot 4-3 \times 90 \cdot 7 & =75 \cdot 9, \\
2 \times 127 \cdot 0+108 \cdot 9-3 \times 90 \cdot 7 & =90 \cdot 8 .
\end{aligned}
$$

By dividing the first of these quantities into the others it is then possible to estimate the regression coefficients:

$$
\begin{aligned}
\text { I02.8/475 } & =0.216 \text { for control milk, } \\
75 \cdot 9 / 475 & =0.160 \text { for air-packed milk, } \\
90 \cdot 8 / 475 & =0.19 \text { I for control milk, pair-fed. }
\end{aligned}
$$

The nutritive value of air-packed milk compared with control milk is thus

$$
100 \times 0.160 / 0.216=74 \% \text {. }
$$

These values do not agree exactly with those given in Table 2 since not all animals ate the whole amount of protein offered them. However, it is an easy matter to correct for this. For example, the actual mean $\mathrm{N}$ intakes for control milk, pair-fed, were 97 and 180 , and $2 \times 180+97-3 \times 0=457$. A more accurate value for the regression coefficient is thus $90.8 / 457=0.199$.

Where no zero level of protein is used it is necessary to estimate liver $\mathrm{N}$ at this level by extrapolation. For example, if there were no zero level in the above experiment there would be three estimates of liver $\mathrm{N}$ at this level:

$$
\begin{aligned}
& 2 \times 1 \mathrm{II} \cdot 9-\mathrm{I} 3 \mathrm{I} \cdot 5=92 \cdot 3 \\
& 2 \times 104 \cdot 4-\mathrm{I} 2 \mathrm{I} \cdot 8=87 \cdot 0 \\
& 2 \times 108 \cdot 9-\mathrm{I} 27 \cdot 0=90 \cdot 8
\end{aligned}
$$

The mean of these, $90 \cdot 0$, estimates liver $\mathrm{N}$ at the zero level of $\mathrm{N}$ intake and could be used if the estimate 90.7 were not available.

An improved estimate of liver $\mathrm{N}$ at the zero level can, in fact, be obtained by combining these various estimates giving the observed value five times as much weight as each calculated value. Here this gives the overall estimate

$$
\frac{5 \times 90 \cdot 7+92 \cdot 3+87 \cdot 0+90 \cdot 8}{8}=90 \cdot 4
$$

and the revised estimates of the regression coefficients are $0.218,0.162$ and 0.193 , respectively. These may, of course, be adjusted for slight variations in protein intake in the manner explained above.

These latter estimates are the more accurate and correspond to estimates formulated for five-point assays (see, for example, Finney, 195 I, 1952). The above approach, however, demonstrates the basis of such formulas as well as indicating whether the results from any diet differ appreciably from a linear response. If a curvilinear response on any diet is suspected from an inspection of the data, this diet need not be used in forming the estimate of the liver $\mathrm{N}$ at the zero level. 


\section{B. Estimation of standard errors}

The first step in assigning standard errors to regression coefficients and their ratios is to estimate the standard deviation of the individual values. This can be done by carrying out an analysis of variance for the Latin-square design in the usual fashion. For Exp. I this takes the form:

\begin{tabular}{lcrr} 
& d.f. & \multicolumn{1}{c}{ s.s. } & m.s. \\
Between litters & 6 & $755 \cdot 9$ & $126 \cdot 0$ \\
Between weight groups & 6 & $515 \cdot 6$ & 85.9 \\
Between treatments & 6 & $8402 \cdot 6$ & $1400 \cdot 4$ \\
Residual & 30 & $1898 \cdot 9$ & 63.3 \\
$\quad$ Total & 48 & $11573 \cdot 0$ &
\end{tabular}

The standard deviation, $s$, of the individual values is thus $\sqrt{ } 6_{3} \cdot 3= \pm 7 \cdot 96$.

Any two regression coefficients may be compared using their ratio, $R$, so that the standard error of this ratio is what is needed in most practical cases. The ratio may, in fact, be calculated directly from the differences indicated in the last section without using the regression coefficients. Thus, for example, the nutritive value of air-packed milk relative to that of control milk is given by the ratio $75 \cdot 9 / \mathrm{ro2} \cdot 8=0 \cdot 74$. In general, the relative nutritive value may be calculated from the ratio of two such differences and

$$
R=D_{1} / D_{2} .
$$

More generally, if some adjustment is made for differing amounts of food intake, the nutritive values may be calculated from

$$
R=a D_{1} / D_{2}
$$

Three standard errors are then available according to the case that is considered. If $n$ is the number of animals on each treatment, these are

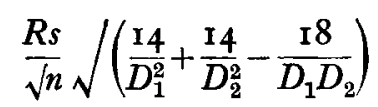

where the zero level is used directly;

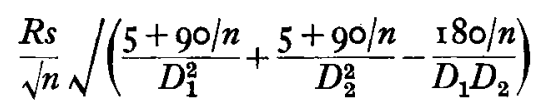

where the zero level is extrapolated;

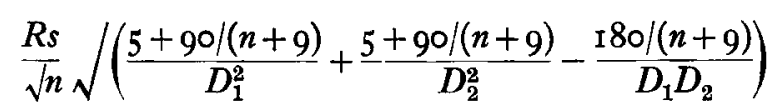

where the zero level is a combined estimate from observation and extrapolation. For example, for the above estimate of 0.74 the standard error is

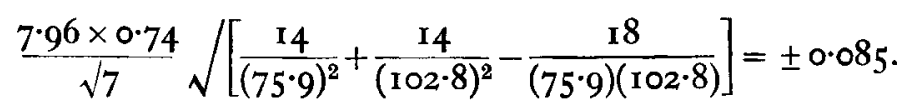

Alternatively, if the combined estimate of 90.4 is used for the zero level, the ratio is $76 \cdot 8 / 103.7=0.74$ and its standard error is

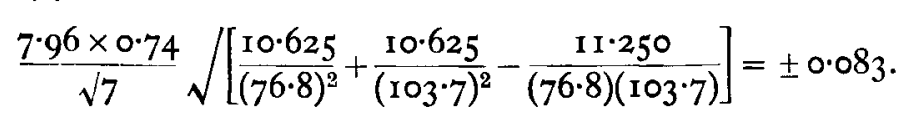




\section{Tests of significance}

An approximate test of significance of the difference between two regression coeffir ients is provided by using the standard errors of the last section. For example, the $95 \%$ confidence limits for the second of the above estimates are $0.74 \pm 0.17$, i.e. 0.57 and 0.91 . The ratio thus differs significantly from unity and the two regression coefficients differ significantly.

Alternatively, the analysis of variance may be extended and components corresponding to different comparisons calculated to allow exact tests to be made. This approach has the advantage of allowing the linearity of the values to be tested at the same time.

Three main components may first be separated: the mean differences between levels, the differences between the linear responses to different protein and the differences between the quadratic responses to different proteins. To demonstrate the form of the analysis Exp. I may be used again.

Table 5. Totals of liver nitrogen for groups of seven rats on different levels of mean daily nitrogen intake, both expressed as $\mathrm{mg}$ nitrogen/100 $\mathrm{g}$ initial body-weight

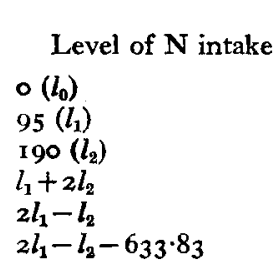

$\begin{array}{cc} & \\ \text { Control milk } & \text { Air-pack milk } \\ 634 \cdot 8 & 634 \cdot 8 \\ 783^{\circ} \cdot 1 & 731 \cdot 2 \\ 920 \cdot 7 & 852 \cdot 3 \\ 2624 \cdot 5 & 2435 \cdot 8 \\ 645 \cdot 5 & 610 \cdot 1 \\ \text { II.67 } & -23 \cdot 73\end{array}$

Control milk
pair-fed
$634 \cdot 8$
$762 \cdot 3$
$888 \cdot 8$
$2539 \cdot 9$
635.8
1.97

Total for all diets
$634 \cdot 8$
$2276 \cdot 6$
$2661 \cdot 8)$ Overall
$7600 \cdot 2$
I $891 \cdot 4$

Table 5 gives the totals of liver $\mathrm{N}$ for the seven rats on each diet. To find the sum of squares between levels it is necessary to use the totals for each level, the divisors being the numbers of animals at each level. Thus the sum of squares for levels is

$$
\frac{(634 \cdot 8)^{2}}{7}+\frac{(2276 \cdot 6)^{2}}{2 I}+\frac{(266 \mathrm{I} \cdot 8)^{2}}{2 \mathrm{I}}-\frac{(5573 \cdot 2)^{2}}{49}=7873 \cdot 0
$$

To find the sum of squares for the differences between linear responses with different proteins it is necessary to use the totals at the first level, $l_{1}$, plus twice the totals at the second level, $l_{2}$. The divisor here is five times the number of rats in each diet. Thus the sum of squares for linear responses is

$$
\left[(2624 \cdot 5)^{2}+(2435 \cdot 8)^{2}+(2539 \cdot 9)^{2}-(7600 \cdot 2)^{2} / 3\right] / 35=5 \text { 10.5. }
$$

That for differences between the quadratic responses is similarly calculated from twice the first level minus the second level:

$$
\left[(645 \cdot 5)^{2}+(610 \cdot 1)^{2}+(635 \cdot 8)^{2}-(1891 \cdot 4)^{2} / 3\right] / 35=19 \cdot 1 \text {. }
$$

These three sums of squares may be added to give the treatment sum of squares. Thus

$$
7873 \cdot 0+510 \cdot 5+19 \cdot 1=8402 \cdot 6 \text {. }
$$

Further partitioning of the treatment sum of squares may be carried out in the normal fashion to test specific comparisons. For example, the sums of squares corresponding 
to the differences between linear and quadratic components of the comparison between control milk and control milk, pair-fed are

$$
\frac{(2624.5-2539 \cdot 9)^{2}}{2 \times 35}=102 \cdot 2 \text { and } \frac{(645 \cdot 5-635 \cdot 8)^{2}}{2 \times 35}=\mathrm{I} \cdot 3
$$

while the sums of squares corresponding to the differences between linear and quadratic components of the comparison between the two control milks and the air-packed milk are

$$
\frac{(2624.5+2539 \cdot 9-2 \times 2435.8)^{2}}{6 \times 35}=408.2 \text { and } \frac{(645.5+635.8-2 \times 610.1)^{2}}{6 \times 35}=\mathrm{I} 7 \cdot 8 \text {. }
$$

The treatment sum of squares may thus be partitioned as follows:

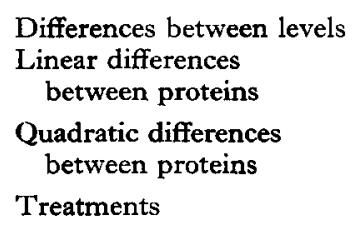

(Control $v$. control pair fed \{Controls $v$. air packed

(Control $v$. control pair fed \{ontrols $v$, air packed

$\begin{array}{cr}\text { d.f. } & \text { s.s. } \\ \text { 2 } & 7873 \cdot 0 \\ \text { I } & 102 \cdot 2 \\ \text { I } & 408 \cdot 2 \\ \text { I } & 1 \cdot 3 \\ \text { I } & 17 \cdot 8 \\ 6 & 8402 \cdot 5\end{array}$

Comparison with the residual mean square, 63.3 , shows quite clearly that, in this instance, only the difference between the linear components of the two control milks and the air-packed milk is of importance, i.e. only the slopes of the regression lines need be considered.

Analyses such as that above may be carried out whether a zero level of protein is tested or not. However, if a zero is included, it is possible to carry out easy tests of the curvature of the responses to each form of protein in turn. This is done by an alternative subdivision of the sums of squares for differences between levels and quadratic differences between proteins.

This further subdivision is accomplished in two steps. First, the component corresponding to the average linear response to protein level is extracted. Here this is

$$
\frac{(7600 \cdot 2-5573 \cdot 2 \times 9 / 7)^{2}}{24}=7872 \cdot 0 \text {. }
$$

In the general case with $p$ proteins and $n$ replicates, $3 p / n$ times the overall total is subtracted from twice the total of the second level plus the total of the first level. This quantity is squared and divided by $p\left(5 n^{2}-18 p n+18 p^{2}+9 p\right) / n$, or, if as is true for Latin-square designs, $n=2 p+\mathrm{I}$, by $p(p+5)$.

Secondly, components corresponding to the quadratic responses are calculated for each protein. In the present instance this is accomplished by subtracting a value, $633.83(=0.0698 \times 1891 \cdot 4+0.790 \times 634.8)$ from twice the first levels minus the second levels. These values, which are shown in the last row of Table 5 , have now to be squared and divided by 35 to give the appropriate sums of squares. Thus

$$
\frac{(\mathrm{II} \cdot 67)^{2}}{35}=3 \cdot 9, \quad \frac{(-23 \cdot 73)^{2}}{35}=\mathrm{I} 6 \cdot \mathrm{I}, \quad \frac{(\mathrm{I} \cdot 97)^{2}}{35}=0 \cdot \mathrm{I} .
$$


In the general case with $p$ proteins and $n$ replicates, the constant to be subtracted is

Twice the total of first level minus total of second level

$$
\begin{aligned}
& 5[\mathrm{I}+p / 5+\sqrt{ }(\mathrm{I}+p / 5)] \\
& +\frac{\text { Total of zero level }}{\sqrt{ }(\mathrm{I}+p / 5)} .
\end{aligned}
$$

The resulting values have then to be squared and divided by $5 n$.

A final subdivision of the treatment sum of squares may now be carried out as follows:

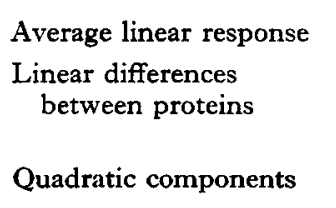

Average linear response

inear differences

\begin{tabular}{|c|c|c|}
\hline & d.f. & $\begin{array}{l}\text { s.s. } \\
7872 \cdot 0\end{array}$ \\
\hline$\left\{\begin{array}{l}\text { Control } v \text {. control pair-fed } \\
\text { Controls } v . \text { air packed }\end{array}\right.$ & $\begin{array}{l}\text { I } \\
\text { I }\end{array}$ & $\begin{array}{l}102 \cdot 2 \\
408 \cdot 2\end{array}$ \\
\hline$\left\{\begin{array}{l}\text { Control milk } \\
\text { Air packed milk } \\
\text { Control milk, pair-fed }\end{array}\right.$ & $\begin{array}{l}\mathbf{I} \\
\mathbf{I} \\
\mathbf{I}\end{array}$ & $\begin{array}{r}3.9 \\
16 \cdot 1 \\
0.1\end{array}$ \\
\hline & 6 & $8402 \cdot 5$ \\
\hline
\end{tabular}

Quadratic components

The linearity of the response to each protein may now be examined and the validity of the assumptions of the analyses established.

\section{Extensive analysis}

The analyses described in the previous sections are valid when the variation in individual intake is not large, but when this is not so standard errors tend to be overestimated and significance underestimated in consequence. To carry out a full analysis in such circumstances is extremely laborious since it is necessary to adopt the procedure of fitting constants after weight and litter effects have been eliminated. Fortunately, however, this can be avoided by using an analysis of covariance.

If an analysis of covariance is used to eliminate the effects of variations in protein intake about the mean levels, a better estimate of the residual mean square may be obtained and, if necessary, further tests of significance carried out. This procedure is not exact since obviously the effects of variations in protein level are not the same for all proteins. However, it proves in many instances to be better than the method of fitting constants since the effects of small variations about the mean protein intakes are often larger than might be expected from the main differences between protein levels. This may apparently be ascribed to variations in food intake in addition to those in level of protein intake (cf. Campbell \& Kosterlitz, 1948).

By this procedure estimates of standard errors may be obtained of sufficient accuracy for all practical purposes. It is this method that has been adopted in estimating the standard errors given in Table 2.

\section{REFERENCES}

Addis, T., Lee, D. D., Lew, W. \& Poo, L. J. (1940). F. Nutr. 19, 199.

Arntich, L., Hunt, C. N., Axelrod, H. E. \& Morgan, A. F. (r95I). F. Nutr. 43, ror.

Block, R. J. \& Mitchell, H. H. (1946-7). Nutr. Abstr. Rev. 16, 249.

Campbell, R. M. \& Kosterlitz, H. W. (1948). F. Physiol. 107, 383.

Campbell, R. M. \& Kosterlitz, H. W. (1950). F. Endocrinol. 6, 308. 
Campbell, R. M. \& Kosterlitz, H. W. (1952). Biochem. Biophys. Acta, 8, 664.

Chick, H. (I 942). Lancet, 242, 405.

Chick, H., Copping, A. M. \& Slack, E. B. (1946). Lancet, 250, I96.

de Loureiro, A. (193 I). Arch. Pat., Lisboa, 3, 72.

Finney, D. J. (1951). F. gen. Microbiol. 5, 223.

Finney, D. J. (1952). Statistical Method in Biological Assay. London: Charles Griffin and Co. Ltd. Guggenheim, K. \& Buechler-Czaczkes, E. (1950). Brit. \%. Nutr. 4, 16r.

Harrison, C. \& Long, C. N. H. (r945). F. biol. Chem. 16r, 545.

Henry, K. M. \& Kon, S. K. (1945). F. Soc, chem. Ind., Lond., 44, 227.

Henry, K. M. \& Kon, S. K. (1952a). F. Dairy Res. 19, 216.

Henry, K. M. \& Kon, S. K. (1952b). Unpublished results.

Henry, K. M., Kon, S. K., Lea, C. H. \& White, J. C. D. (1948). F. Dairy Res. 15, 292.

Kosterlitz, H. W. (1944). Nature, Lond. 154, 207.

Kosterlitz, H. W. (1947). F. Physiol. ro6, 194.

Mandel, P., Jacob, M. \& Mandel. L. (1950). Bull. Soc. Chim. biol., Paris, 32, 80.

Mitchell, H. H. (1923-4). F. biol. Chem. 58, 873 .

Mitchell, H. H. (1947). Arch. Biochem. 12, 293.

Mitchell, H. H. \& Carman, G. G. (1926). F. biol. Chem. 68, 183.

Neuberger, A. \& Webster, T. A. (I945). Biochem. F. 39, 200.

Yuen, D. W., Poo, L. G., Lew, W. \& Addis, T. (1940). Amer. F. Physiol. 129, 685.

\title{
The Effect of Sulphonamides and of Cooking or Grinding the Diet on the Excretion of Vitamins of the B Complex by the Refected Rat
}

\author{
By J. E. FORD, KATHLEEN M. HENRY, S. K. KON, J. W. G. PORTER, \\ S. Y. THOMPSON AND F. W. WILBY \\ National Institute for Research in Dairying, University of Reading
}

(Received 21 Fanuary 1952)

Refection in rats was first recognized by Fridericia ( 1926 ), who described the condition as 'a transmissible change in the intestinal content, enabling rats to grow and thrive without B-vitamin in the food'. The existence of refection has been confirmed by later workers (cf. review by Kon, 1945), but the full mechanism of establishing and maintaining the refected state has not yet been satisfactorily explained.

It is now known that the intestinal flora of rats, and indeed of most animals, synthesizes all the well-characterized vitamins of the B complex. The contribution of this microbial synthesis to the vitamin requirements of rats on normal diets is relatively small, but refected rats are evidently able to derive the whole of their B vitamins from the products of such synthesis. Thus either the total amount of vitamins synthesized must be greater in the refected than in the normal rat or the efficiency of utilization must be higher or, more probably, both. Kon, Kon \& Mattick (1938) suggested that the presence of undigested starch in the caecum of the refected rat, along with the requisite starch-splitting enzymes led to a vigorous fermentation and a resulting acid $\mathrm{pH}$ that created conditions favourable for both vitamin synthesis and absorption.

During recent years the effect of sulphonamides on the synthetic activities of intestinal micro-organisms has been extensively studied, and much valuable information 